\title{
Hepatitis B Surface Antibody Negative
}

National Cancer Institute

\section{Source}

National Cancer Institute. Hepatitis B Surface Antibody Negative. NCI Thesaurus. Code C153244.

An indication that antibodies that recognize a hepatitis B virus surface protein have not been detected in a sample. 